\title{
Glutamine transport by mouse inner cell masses
}

\author{
M. B. Jamshidi and P. L. Kaye* \\ Department of Physiology and Pharmacology, The University of Queensland, Brisbane, QLD 4072, \\ Australia
}

\begin{abstract}
Mouse blastocysts take up glutamine by specific transport systems. Glutamine is an important precursor for macromolecular synthesis and a potential alternative fuel to glucose. This study compared glutamine uptake in blastocysts and isolated inner cell masses and characterized the major participating systems in the latter. Inner cell masses take up glutamine by facilitated transport systems. The identity of these was investigated using substrate competition and kinetic studies. $\mathrm{Na}^{+}$-dependent uptake of $13 \mu \mathrm{mol}$ glutamine $\mathrm{l}^{-1}$ was inhibited by $60 \%$ by $1 \mathrm{mmol}$ tryptophan $\mathrm{l}^{-1}, 25 \%$ by $1 \mathrm{mmol} 2$-amino-2norbornanecarboxylic acid $1^{-1}$ and $50 \%$ by $1 \mathrm{mmol}$ lysine $1^{-1}$. Furthermore, $1 \mathrm{mmol}$ 2-methyl(amino)isobutyric acid (MeAIB) $\mathrm{I}^{-1}$ inhibited uptake by $29 \%$. Kinetic analysis of MeAIB-resistant uptake revealed a predominant $\mathrm{Na}^{+}$-dependent facilitated uptake system with $K_{\mathrm{m}}$ and $V_{\max }$ values of $434 \pm 72 \mu \mathrm{mol} \mathrm{l}^{-1}$ and $237 \pm 38 \mathrm{fmol}$ per inner cell mass per 10 min, respectively. The inhibition of $\mathrm{Na}^{+}$-dependent uptake by tryptophan, lysine and the analogue 2-amino-2-norbornanecarboxylic acid suggests that most uptake of glutamine by inner cell masses occurs via the same system that predominates in whole blastocysts, $\mathrm{B}^{\mathrm{O},+}$. The period of assay was so brief that significant participation of the inner cell mass in whole blastocyst uptake was precluded showing that system $\mathrm{B}^{\mathrm{O},+}$ is expressed by both the trophectoderm and inner cell mass components of the blastocyst. However, MeAIB inhibited uptake by inner cell masses but not by blastocysts. This MeAIB-sensitive uptake had a $K_{\mathrm{m}}$ value of $4.3 \pm 1.7 \mathrm{mmol}^{-1}$ and a $V_{\max }$ value of $451 \pm 119 \mathrm{fmol}$ per inner cell mass per $10 \mathrm{~min}$. These characteristics suggest the first embryonic appearance of system A, which is a common $\mathrm{Na}^{+}$-dependent transporter in many somatic cells. Significant inhibition of $\mathrm{Na}^{+}$-independent glutamine uptake by tryptophan suggests participation of the ubiquitous system $\mathrm{L}$, while inhibition by lysine suggests that $b^{0,+}$ may also be expressed in inner cell masses. Thus glutamine uptake by inner cell masses occurs via several transport systems expressed in whole blastocysts, including $\mathrm{Na}^{+}$-dependent system $\mathrm{B}^{\mathrm{O},+}$, and probably $\mathrm{Na}^{+}$-independent systems $\mathrm{L}$ and $b^{\mathrm{O},+}$, but is supplemented by the first expression of $\mathrm{Na}^{+}$-dependent system $\mathrm{A}$ in these cells from which the fetus later develops.
\end{abstract}

\section{Introduction}

Glutamine is a precursor for protein and pyrimidine biosynthesis in addition to being implicated in nitrogen metabolism. In many cells, conversion of glutamine to $a$-ketoglutarate can provide a significant source of energy and lead to conversion of the carbon backbone into other amino acids. Glutamine is necessary for the culture of many cells in vitro and is required at concentrations 5-10 times higher than other amino acids (Eagle, 1955).

During preimplantation development, glutamine may provide an alternative to glucose as an energy source for bovine blastocysts (Rieger and Guay, 1988) and it has been suggested that it is an energy source in preimplantation mouse embryos at all stages (Chatot et al., 1990). In mice, glutamine is abundant in oviduct fluid (Gardner and Leese, 1990).

* Correspondence and reprint requests.

Revised manuscript received 7 February 1995
Mouse embryos express facilitated transport systems capable of carrying this amino acid across the plasma membrane from the two-cell stage, and uptake increases significantly as differentiation of the blastocyst occurs (Gardner et al., 1989; Chatot et al., 1990; Lewis and Kaye, 1992). However, it is not known whether, in the blastocyst, this glutamine can be provided to cells of the inner cell mass, since there is no knowledge of glutamine uptake activity in this tissue.

The aim of this study was to classify glutamine transport systems in inner cell mass cells, using studies of $\mathrm{Na}^{+}$requirement, substrate inhibition profiles and kinetics of uptake by immunosurgically isolated inner cell masses.

\section{Materials and Methods}

Embryos

Quackenbush mice were randomly bred in our own animal house with lights on between 06:00 and 18:00 h. At 10 weeks 
of age, mice were superovulated by an injection with 10 iu pregnant mares' serum gonadotrophin i.p. (Folligon: Intervet, Lane Cove, NSW) at 10:00 h; followed $48 \mathrm{~h}$ later by $10 \mathrm{iu} \mathrm{hCG}$ (Chorulon: Intervet). At this time, the injected females were placed with single males of the same strain and the presence of a vaginal plug $23 \mathrm{~h}$ later indicated mating. Blastocysts $(96 \mathrm{~h}$ after hCG treatment) were collected from the mated mice and washed in M2 medium (Fulton and Whittingham, 1978; modified as described by Hobbs and Kaye, 1985). Kinetic studies were performed on inner cell masses isolated from blastocysts that had developed in vivo and blastocysts that had developed from two-cell embryos ( $48 \mathrm{~h}$ after hCG treatment) during $48-52 \mathrm{~h}$ culture in vitro in $20 \mu \mathrm{l}$ droplets of BMOC2 medium (Brinster, 1965), modified as described by Pemble and Kaye (1986), under paraffin oil in an atmosphere of $\mathrm{H}_{2} \mathrm{O}$ saturated $5 \% \mathrm{CO}_{2}, 5 \% \mathrm{O}_{2}$ and $90 \% \mathrm{~N}_{2}$ at $37^{\circ} \mathrm{C}$. Previous experiments confirmed that under these conditions at least $50 \%$ of two-cell embryos ( $48 \mathrm{~h}$ after hCG treatment) developed to blastocysts by $96 \mathrm{~h}$ after hCG treatment.

\section{Isolation of inner cell masses}

The zonae pellucidae were removed by brief exposure to

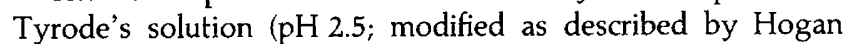
et al., 1986) before immediate transfer through three $2 \mathrm{ml}$ washes of M2. The zonae-free blastocysts were then placed in rabbit anti-mouse spleen cell antiserum diluted $1: 10$ (v:v) in M2 for $13 \mathrm{~min}$. The antiserum was produced in a New Zealand White rabbit, bled 10 days after three injections i.v., 6 days apart, of Quackenbush mouse spleen cells in $0.5 \mathrm{ml} 0.9 \%(\mathrm{w} / \mathrm{v})$ sterile saline (Solter and Knowles, 1975; Harvey and Kaye, 1990). The blastocysts were then washed with fresh M2 and placed in guinea-pig serum diluted 1:10 in $\mathrm{M} 2$ for $13 \mathrm{~min}$ (ICN Biomedicals, Costa Mesa), as a source of complement. Inner cell masses were freed of lysed trophectoderm cells by passage through a fine hand drawn pipette. About $75 \%$ of blastocysts yielded suitable inner cell masses.

\section{$\mathrm{Na}^{+}$-free $\mathrm{M} 2$ medium}

$\mathrm{M} 2$ medium, free of $\mathrm{Na}^{+}\left(\mathrm{M}_{2}-\mathrm{Na}^{+}\right)$, was prepared by equimolar replacement of $\mathrm{NaCl}$ with choline chloride and $\mathrm{NaHCO}_{3}$ with $\mathrm{KHCO}_{3}$. The hepes used to buffer this medium was adjusted to $\mathrm{pH} 7.4$ with $\mathrm{KOH}$, and sodium lactate was omitted. Previous experiments had shown that omission of lactate did not affect blastocyst development over $4 \mathrm{~h}$ in vitro, or amino acid transport rates in blastocysts (Hobbs and Kaye, 1986).

The medium was added to the freeze-dried radiolabelled substrate, mixed and then transferred to the culture dish and preincubated under paraffin oil at $37^{\circ} \mathrm{C}$, for at least $1 \mathrm{~h}$.

\section{Glutamine uptake}

Glutamine uptake was determined by transferring blastocysts or inner cell masses to $20 \mu \mathrm{l}$ drops of M2 containing 9-13 $\mu \mathrm{mol}\left[{ }^{3} \mathrm{H}\right.$ ]glutamine $\mathrm{l}^{-1}$ (33-55 $\mathrm{Ci} \mathrm{mmol}^{-1}$, Amersham International, Bucks) under liquid paraffin in a Petri dish that had been equilibrated at $37^{\circ} \mathrm{C}$.
The blastocysts or inner cell masses were collected, washed thoroughly by transfer through four changes of $2 \mathrm{ml}$ ice cold $\mathrm{M} 2$ and placed in separate vials containing $0.2 \mathrm{ml} \mathrm{H}_{2} \mathrm{O}$ to which was added $1 \mathrm{ml}$ of Optiphase 'Hisafe 3' scintillation cocktail (Optiphase 'Hisafe' 3: LKB; FSA Laboratory Supplies, Loughborough) before the radioactivity was determined in a Packard 1900 CA liquid scintillation counter at $40 \%$ efficiency, with an absolute background of 4-7 c.p.m.

\section{Efflux of $\left.\Gamma^{3} H\right]$ lolutamine}

Inner cell masses were preincubated for $10 \mathrm{~min}$ at $37^{\circ} \mathrm{C}$ in $\mathrm{M} 2$ containing $100 \mu \mathrm{mol}$ or $1 \mathrm{mmol}\left[{ }^{3} \mathrm{H}\right.$ lglutamine $\mathrm{l}^{-1}$ $\left(0.5 \mathrm{Ci} \mathrm{l}^{-1}\right)$, collected and rapidly washed in $\mathrm{M} 2$, before transfer to $\mathrm{M} 2$ lacking glutamine at $37^{\circ} \mathrm{C}$. At various times inner cell masses were collected, washed in ice-cold M2 and radioactivity was determined as above.

\section{Competition by other amino acids}

Blastocysts or inner cell masses were incubated for $10 \mathrm{~min}$ in $\mathrm{M} 2$ containing $9-13 \mu \mathrm{mol}\left[{ }^{3} \mathrm{H}\right]$ glutamine $\mathrm{I}^{-1}$ and one of the following at $1 \mathrm{mmol} \mathrm{l}^{-1}$ : bicyclic analogue, 2-amino2-norbornanecarboxylic acid $(\mathrm{BCH})$; lysine (Lys); tryptophan (Trp); or 2-methyl(amino)isobutyric (MeAIB), and $\left.{ }^{3} \mathrm{H}\right]$ glutamine uptake was determined as above.

\section{Standardization}

The specific radioactivity of each drop was determined from samples of the medium collected at the end of the uptake period and the known non-radiolabelled glutamine concentration, allowing for $\left[{ }^{3} \mathrm{H}\right]$ glutamine contribution. A sample of the final wash was used to determine the experimental background radioactivity, which was found to be the same as the absolute background.

\section{Statistical analyses}

In cases where the data were not normally distributed, they were normalized by logarithmic transformation. The statistical significance of differences between means was assessed by multiple-range test (Fisher's protected LSD) after analysis of variance of normalized data. Kinetic parameters for saturable glutamine uptake were determined by fitting data to the equation

$$
v=\mathrm{K}_{\mathrm{o}}[\mathrm{glyn}]+\left(\left\{V_{\text {max }}[\mathrm{g} \ln ]\right\}\left\{\mathrm{K}_{\mathrm{m}}+[\mathrm{g} \ln ]\right\}^{-1}\right)
$$

using non-linear regression, where $v$ is the initial rate or uptake in fmol per inner cell mass per $10 \mathrm{~min}, \mathrm{~K}_{0}$ is the rate constant for the non-saturable transport, and $K_{\mathrm{m}}\left(\mu \mathrm{mol} 1^{-1}\right)$ and $V_{\max }$ (fmol per inner cell mass per $10 \mathrm{~min}$ ) values are the kinetic parameters describing the saturable transport component (Hobbs and Kaye, 1990).

\section{Results}

Initial experiments confirmed that over $95 \%$ of $13 \mu \mathrm{mol}$ $\left.{ }^{3} \mathrm{H}\right]$ glutamine $\mathrm{l}^{-1}$ taken up by inner cell masses during $10 \mathrm{~min}$ 


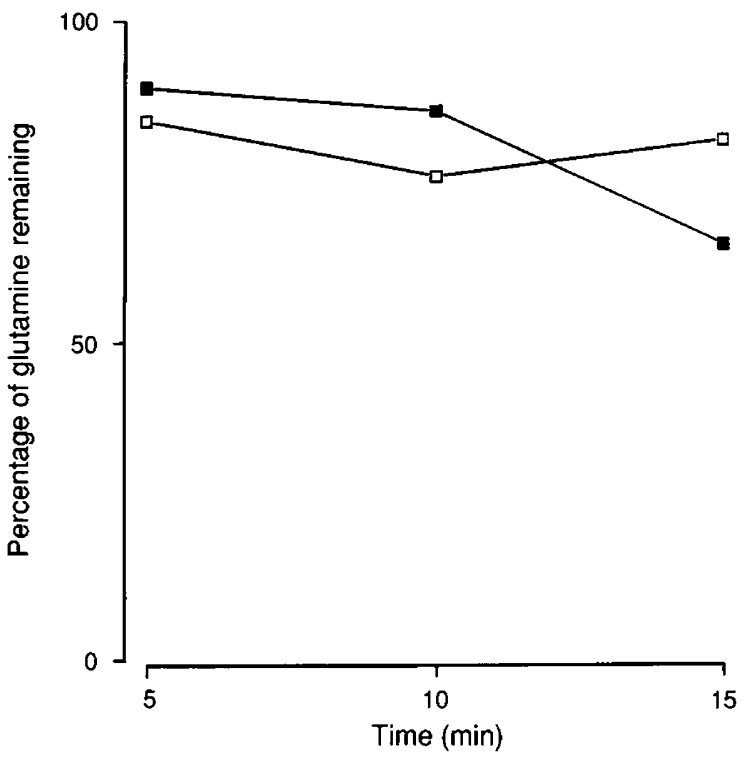

Fig. 1. Percentage of $\left[{ }^{3} \mathrm{H}\right]$ glutamine remaining at $37^{\circ} \mathrm{C}$ from mouse inner cell masses preloaded with $100 \mu \mathrm{mol}(\square)$, or $1 \mathrm{mmol}(\square)$ $\left[{ }^{3} \mathrm{H}\right]$ glutamine $1^{-1}$ for $10 \mathrm{~min}$ at $37^{\circ} \mathrm{C}$. Values are the percentage of initial radioactivity remaining based on means \pm SEM of three experiments, each containing 6-12 inner cell masses.

at $37^{\circ} \mathrm{C}$ was soluble in $10 \% \mathrm{Cl}_{3} \mathrm{C}_{2} \mathrm{O}_{2} \mathrm{H}$. There was no significant loss of preaccumulated $\left[{ }^{3} \mathrm{H}\right]$ glutamine from inner cell masses into amino acid-free medium at $37^{\circ} \mathrm{C}$ after preloading with $100 \mu \mathrm{mol}$ or $1 \mathrm{mmol}\left[{ }^{3} \mathrm{H}\right]$ glutamine $\mathrm{I}^{-1}$ medium (Fig. 1 ). The rates of uptake of $13 \mu \mathrm{mol}\left[{ }^{3} \mathrm{H}\right]$ glutamine $1^{-1}$ by blastocysts and inner cell masses were compared in parallel experiments on blastocysts and inner cell masses collected from the same group of superovulated mice. The rates determined by least squares linear regression were $2.26 \pm 0.05 \mathrm{fmol}$ per blastocyst $\min ^{-1}$ and $0.72 \pm 0.06 \mathrm{fmol}$ per inner cell mass $\min ^{-1}$ (Fig. 2).

\section{Competition by other amino acids}

In blastocysts, $14 \mu \mathrm{mol}\left[{ }^{3} \mathrm{H}\right]$ glutamine $\mathrm{l}^{-1}$ uptake was inhibited $60 \%$ by $1 \mathrm{mmol} \operatorname{Trp~}^{-1}(P<0.01)$ and about $25 \%$ by BCH $(P<0.01$, Fig. 3). Multiple range testing of the differences between the means showed that the 10\% inhibition by MeAIB was not significant at $P<0.05$, but that the $25 \%$ inhibition by $\mathrm{BCH}$ was significant at $P<0.01$.

In inner cell masses, both $\mathrm{MeAIB}$ and $\mathrm{BCH}$ significantly inhibited glutamine uptake by $25-30 \%(P<0.01)$. As in blastocysts, $\operatorname{Trp}$ caused a $60 \%$ inhibition $(P<0.01)$.

\section{Uptake of other amino acids in the presence of MeAIB}

Preliminary investigations of the uptake of $15.6 \mu \mathrm{mol}$ $\left[{ }^{3} \mathrm{H}\right]$ glutamine $\mathrm{I}^{-1}$ and $6.3 \mu \mathrm{mol}\left[{ }^{3} \mathrm{H}\right]$ leucine $\mathrm{I}^{-1}$ in the presence

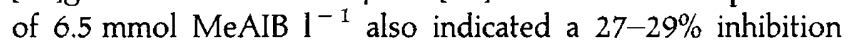
(Fig. 4).

\section{$\mathrm{Na}^{+}$dependence}

About $75 \%$ of the uptake of $13 \mu \mathrm{mol}$ glutamine $1^{-1}$ by inner cell masses required the presence of $\mathrm{Na}^{+}$(Fig. 5). The

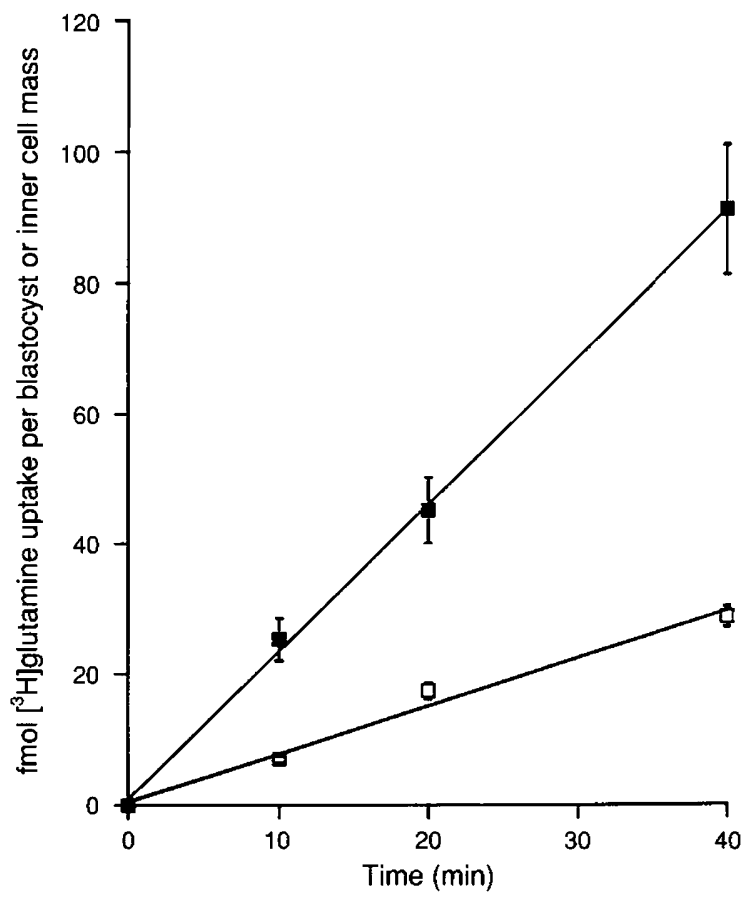

Fig. 2. Uptake of $13 \mu \mathrm{mol}\left(0.5 \mathrm{Ci} \mathrm{I}^{-1}\right)\left[{ }^{3} \mathrm{H}\right]$ glutamine $\mathrm{l}^{-1}$ into mouse blastocysts $(\square)$ and inner cell masses $(\square)$. Values are means \pm SEM of three experiments, each containing 4-6 embryos or inner cell masses per time point. Lines fitted by least squares linear regression.

$\mathrm{Na}^{+}$-independent uptake was inhibited strongly $(50 \%$, $P<0.01)$ by $1 \mathrm{mmol} \operatorname{Trp} \mathrm{l}^{-1}$, moderately $(20 \%$, $0.01<P<0.05)$ by 1 mmol Lys $1^{-1}$, but not at all by $1 \mathrm{mmol}$ $\mathrm{MeAIB} 1^{-1}$. In contrast, the $\mathrm{Na}^{+}$-dependent component was inhibited strongly $(68 \%, P<0.01)$ by $1 \mathrm{mmol} \operatorname{Trp~} \mathrm{l}^{-1},(50 \%$, $P<0.01)$ by $1 \mathrm{mmol}$ Lys $\mathrm{I}^{-1}$, and moderately $(20 \%$, $0.01<P<0.05$ ) by $1 \mathrm{mmol}$ MeAIB I ${ }^{-1}$.

\section{Kinetics}

MeAIB-resistant uptake. The contribution to $\mathrm{Na}^{+}$-dependent glutamine uptake by the MeAIB-sensitive system was blocked by inclusion of $2 \mathrm{mmol} \mathrm{MeAIB} \mathrm{l}{ }^{-1}$. In the absence of $\mathrm{Na}^{+}$, the rate of glutamine uptake appeared to increase linearly with glutamine concentration to $5 \mathrm{mmol} \mathrm{l}^{-1}$ (Fig. 6). In the presence of $\mathrm{Na}^{+}$, above approximately $500 \mu \mathrm{mol}$ glutamine $\mathrm{l}^{-1}$, the total rate of uptake appeared to increase proportionally to the increase in glutamine concentrations. The slope in this portion of the curve was similar to that observed in the absence of $\mathrm{Na}^{+}$. This finding suggested that a combination of $\mathrm{Na}^{+}$independent nonsaturable uptake and a $\mathrm{Na}^{+}$-dependent saturable system was operating in inner cell masses to take up glutamine.

The apparent combination of saturable and nonsaturable uptake could be described by the equation

$$
v=\mathrm{K}_{\mathrm{o}}[\mathrm{G} \ln ]+\left(\left\{V_{\max }[\mathrm{G} \ln ]\right\}\left\{K_{\mathrm{m}}+[\mathrm{G} \ln ]\right\}^{-1}\right) .
$$

The value of $K_{0}$ was assumed to approximate to that of the $\mathrm{Na}^{+}$-dependent uptake, that is, $66 \pm 2 \mathrm{pl}$ per inner cell mass per $10 \mathrm{~min}$, calculated by linear regression (Fig. $6 ; r=0.996 ; n=5$ ). 


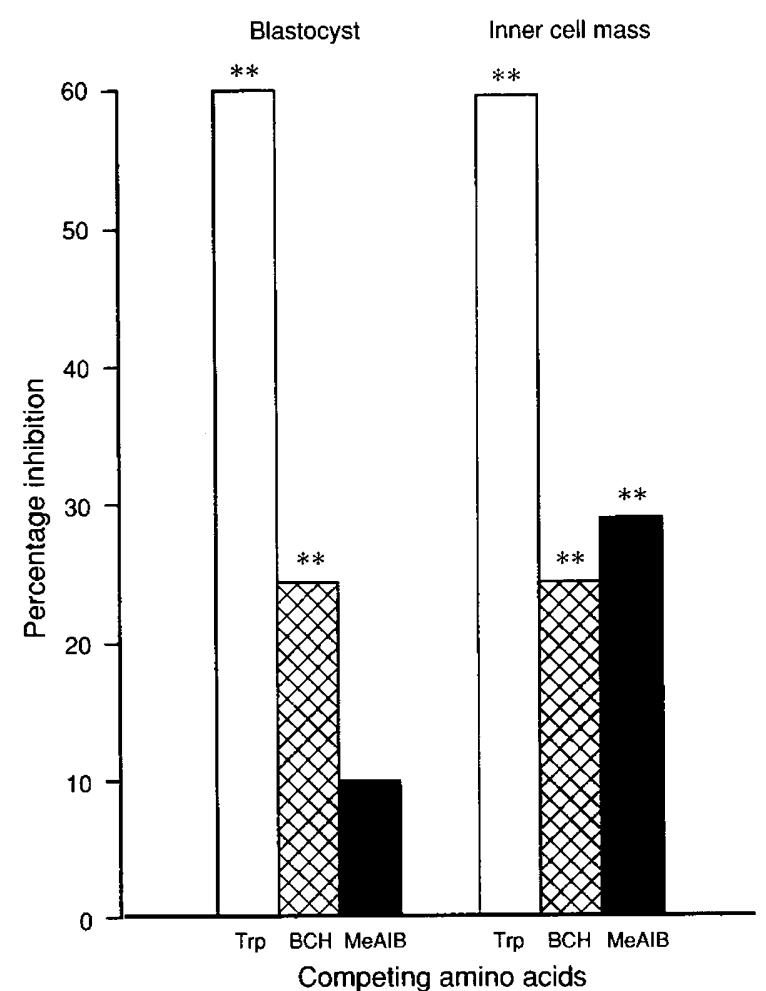

Fig. 3. Percentage inhibition of $\left[{ }^{3} \mathrm{H}\right]$ glutamine uptake by mouse blastocysts and inner cell masses in the presence of tryptophan (Trp), 2-amino-2-norbornanecarboxylic acid $(\mathrm{BCH})$ or methyl(amino)isobutyric acid (MeAIB). Inhibition is calculated from the means as [(control-inhibitor) control $\left.{ }^{-1}\right] \% . * * P<0.01$ when tested by multiple-range test. Control values for blastocysts and inner cell masses were $23 \mathrm{fmol}$ per blastocyst per $10 \mathrm{~min}$ and $10 \mathrm{fmol}$ per inner cell mass per $10 \mathrm{~min}$, respectively.

This value was then used to fit the curve for uptake in the presence of $\mathrm{Na}^{+}$to the equation above. This procedure reduced the total variance of the fit and yielded estimates of the parameters for the saturable system of $V_{\text {rnax }}=237 \pm 38 \mathrm{fmol}$ per inner cell mass per $10 \mathrm{~min}$ and $K_{\mathrm{m}}=434 \pm 72 \mu \mathrm{mol} \mathrm{l} \mathrm{l}^{-1}$ (Fig. 6).

Lysine-resistant uptake. To examine the kinetics of the major $\mathrm{Na}^{+}$-dependent Lys-resistant system, glutamine uptake was analysed in the presence of $20 \mathrm{mmol}$ Lys $\mathrm{I}^{-1}$. The possibility that the expression of MeAIB-resistant uptake was affected by developmental conditions was examined by conducting separate experiments on inner cell masses isolated from blastocysts which had developed in vivo and in vitro. The uptake rates for inner cell masses in the presence of $\mathrm{Na}^{+}$were not significantly different whether they were isolated from blastocysts that had developed in vivo or in vitro. The results for inner cell masses from both sources were combined. The $\mathrm{K}_{0}$ was determined from $\mathrm{Na}^{+}$-independent uptake to be $77 \pm 3 \mathrm{pl}$ per inner cell mass per $10 \mathrm{~min}$ by linear regression (Fig. $7 ; r=0.998$; $n=8)$ and the $\mathrm{Na}^{+}$-dependent component yielded the following kinetic estimates: $K_{\mathrm{m}}=4.3 \pm 1.7 \mathrm{mmol} \mathrm{l}^{-1}$ and $V_{\max }=451 \pm 119 \mathrm{fmol}$ per inner cell mass per $10 \mathrm{~min}$ by non-linear regression (Fig. 7).

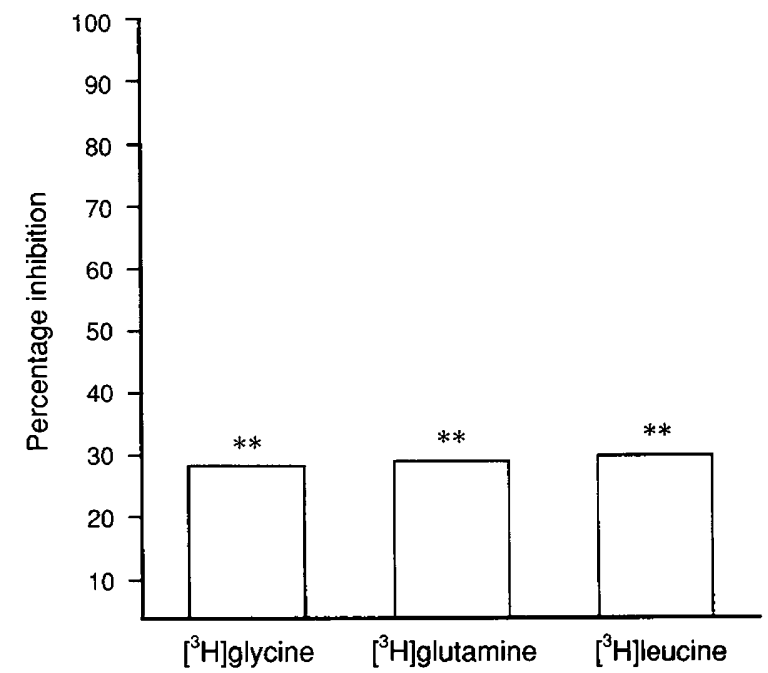

Fig. 4. Percentage inhibition of uptake of $15.6 \mu \mathrm{mol}\left[{ }^{3} \mathrm{H}\right]$ glycine $1^{-1}$, $6.3 \mu \mathrm{mol}\left[{ }^{3} \mathrm{H}\right]$ leucine $1^{-1}$ or $14 \mu \mathrm{mol}\left[{ }^{3} \mathrm{H}\right]$ glutamine $\mathrm{I}^{-1}$ by mouse inner cell masses in the presence of $5 \mathrm{mmol}$ glutamine $\mathrm{l}^{-1}$ or $6.5 \mathrm{mmol}$ methylaminoisobutyric acid $\mathrm{I}^{-1}$. Inhibition was calculated from the means as [(control - inhibitor) control $\left.{ }^{-1}\right] \%$. Bars are means from 3--5 experiments, each containing 4-10 inner cell masses. $* * P<0.01$, when tested by multiple range test. Control uptake values were $316 \mathrm{fmol}$ per inner cell mass per $10 \mathrm{~min}$ for $\left[{ }^{3} \mathrm{H}\right] g l y c i n e$, $10.6 \mathrm{fmol}$ per inner cell mass per $10 \mathrm{~min}$ for $\left[{ }^{3} \mathrm{H}\right]$ glutamine and $454 \mathrm{fmol}$ per inner cell mass per $10 \mathrm{~min}$ for $\left[{ }^{3} \mathrm{H}\right]$ leucine.

\section{Discussion}

Tests assessing the fixation of $\left[{ }^{3} \mathrm{H}\right]$ glutamine into acid-insoluble material (mainly protein) during the incubation showed that $95 \%$ of the glutamine remained in the inner cell masses as acid-soluble material. Thus $\left[{ }^{3} \mathrm{H}\right]$ glutamine uptake was accurately reflecting the simple uptake of glutamine by the inner cell masses, which is similar to the situation for blastocysts (Lewis and Kaye, 1992).

Kinetic studies require estimation of an initial rate. Parallel studies of glutamine uptake in blastocysts and inner cell masses were made to enable accurate comparisons. The results for blastocysts reflected those reported earlier (Lewis and Kaye, 1992).

In inner cell masses at $13 \mu \mathrm{mol}$ glutamine $1^{-1}$, the rate was only about $30 \%\left(0.7 \mathrm{fmol}\right.$ per inner cell mass $\left.\min ^{-1}\right)$ of that in blastocysts, with no indication of equilibrium even after $40 \mathrm{~min}$ of uptake, supporting predictions of very little efflux of glutamine from the inner cell mass.

In the presence of $\operatorname{Trp}$ or $\mathrm{BCH}$, significant inhibition of glutamine uptake into inner cell masses was apparent, as in blastocysts. This inhibition suggested a contribution of system $\mathrm{B}^{\mathrm{O},+}$ to glutamine uptake by inner cell masses, as was concluded earlier for blastocysts (Lewis and Kaye, 1992).

Other identifying data came from the kinetic studies. The inclusion of MeAIB was designed to block the contribution of the other major $\mathrm{Na}^{+}$-dependent saturable system indicated by the inhibition studies. The inner cell mass $K_{\mathrm{m}}$ value of $434 \pm 72 \mu \mathrm{mol} \mathrm{I}^{-1}$ for glutamine was not significantly different by $t$ test from the $524 \pm 75 \mu \mathrm{mol} \mathrm{l} l^{-1}$ reported for $\mathrm{Na}^{+}$. dependent uptake of glutamine by whole blastocysts (Lewis and Kaye, 1992). The equivalent $K_{\mathrm{m}}$ values suggest identity 


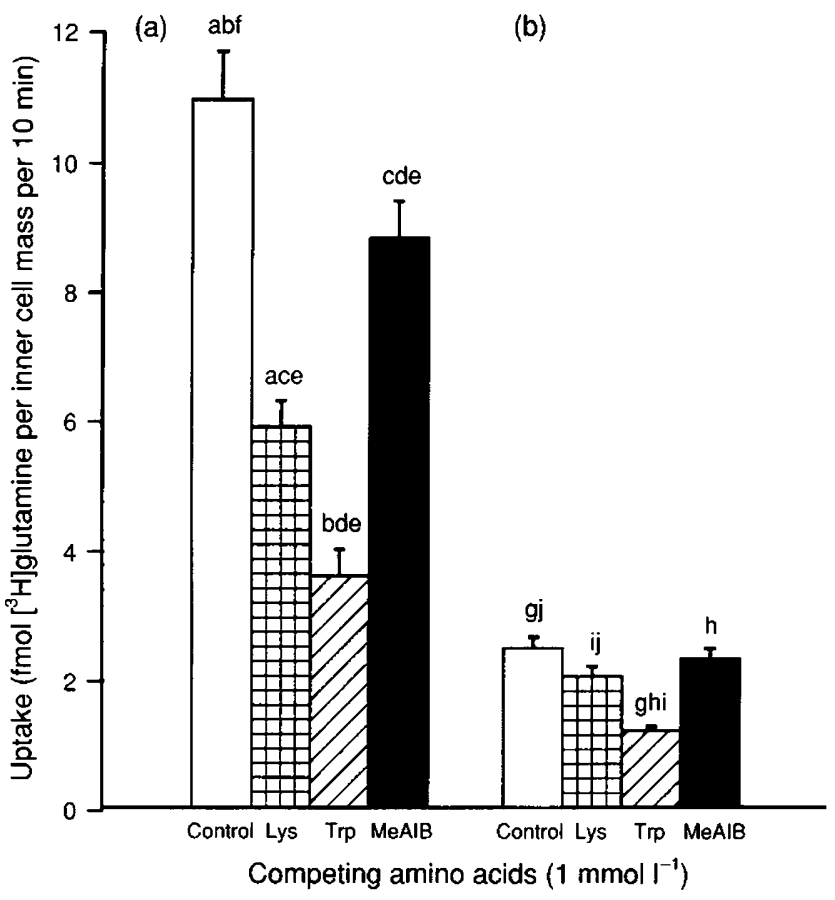

Fig. 5. Uptake of $13 \mu \mathrm{mol}\left[{ }^{3} \mathrm{H}\right]$ glutamine $1^{-1}$ by mouse inner cell masses in (a) presence or (b) absence of $\mathrm{Na}^{+}$and in the presence of $1 \mathrm{mmol}$ lysine (Lys) $\mathrm{I}^{-1}$, methyl(amino)isobutyric acid (MeAIB) or tryptophan (Trp). Means with identical superscripts are significantly different by multiple range test; ${ }^{f, j} 0.01<P<0.05$; $^{\text {a,b,c,d,e,g,h,i }} P<0.01$. Values are means \pm SEM from three experiments, each containing 5-10 inner cell masses per treatment.

between the MeAIB-resistant, $\mathrm{Na}^{+}$-dependent system in inner cell masses and the major $\mathrm{Na}^{+}$-dependent system in blastocysts, which was concluded to be $B^{0,+}$ (Lewis and Kaye, 1992). The strong inhibitions by $\operatorname{Trp}$ and $\mathrm{BCH}$ support this conclusion, as both are strong competitors for $\mathrm{B}^{\mathrm{O}^{+}}$uptake (Van Winkle, 1988). The $V_{\max }$ value of $237 \pm 38 \mathrm{fmol}$ per inner cell mass per $10 \mathrm{~min}$ is close to that for methionine uptake by inner cell masses $(280 \mathrm{fmol}$ per inner cell mass per $10 \mathrm{~min}$; Miller and Schultz, 1985) and this similarity suggests the major $\mathrm{Na}^{+}$. dependent system transporting these two amino acids in inner cell masses is indeed $\mathrm{B}^{\mathrm{O},+}$.

The estimated diffusion rate in inner cell masses was 66-77 pl per inner cell mass per $10 \mathrm{~min}$. This is $50 \%$ greater than the value in blastocysts $(40 \mathrm{pl}$ per embryo per $10 \mathrm{~min}$; Hobbs and Kaye, 1985). However, since uptake over these short periods probably reflects trophectoderm activity, it may be concluded that the tight junctions between these epithelial cells present a significant barrier to diffusion of glutamine in whole blastocysts that is not present in inner cell masses. Thus blastocysts revealed a lower diffusion rate than did inner cell masses, because of the resistance that these tight junctions present to paracellular diffusion. This conclusion is further supported by the fact that the high concentration of amino acids in the uterus of rabbits $\left(25.5 \mathrm{mmol} \mathrm{l}^{-1}\right)$ is not reflected within the blastocoel (12.1 mmol $\mathrm{l}^{-1}$; Miller and Schultz, 1987).

Another finding of this study was the demonstrated appearance of the MeAIB-sensitive system. As MeAIB is exclusively

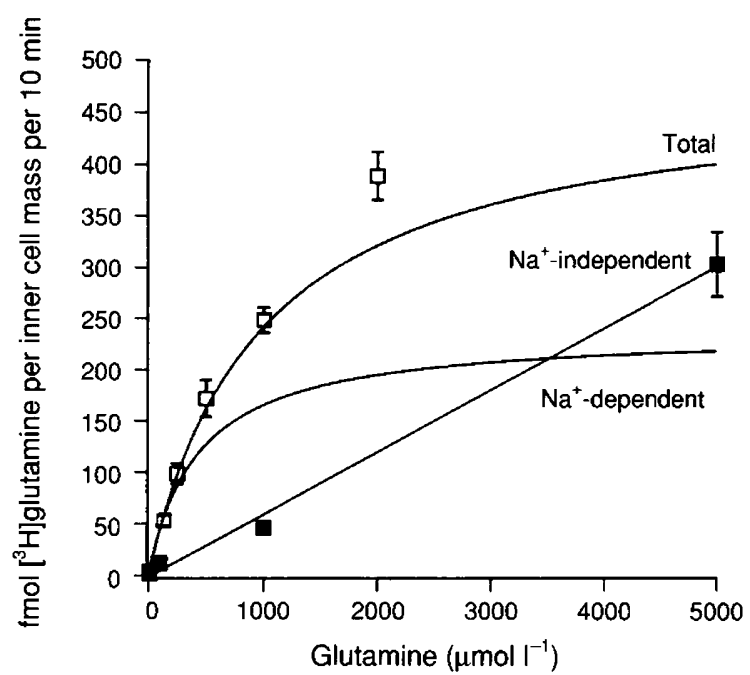

Fig. 6. Kinetics of glutamine uptake by mouse inner cell masses at $37^{\circ} \mathrm{C}$ in the presence of $5 \mathrm{mmol}$ methyl(amino)isobutyric acid $1^{-1}$ $\pm \mathrm{Na}^{+}$. Inner cell masses were collected from expanded blastocysts cultured for $48-52 \mathrm{~h}$ from two-cell stage embryos in BMOC2 medium. The curve for total uptake data $(\square)$ is fitted to the equation $v=\mathrm{K}_{\mathrm{o}}[\mathrm{Gln}]+\left(\left\{V_{\max }[\mathrm{Gln}]\right\}\left\{K_{\mathrm{m}}+[\mathrm{Gln}]\right\}^{-1}\right)$, with $\mathrm{K}_{\mathrm{o}}$ set to $66 \mathrm{pl}$ per inner cell mass per $10 \mathrm{~min}$ obtained from $\mathrm{Na}^{+}$-independent uptake data by linear regression ( $\boldsymbol{\sigma}$ ). The $\mathrm{Na}^{+}$-dependent curve is fitted to the equation $v=V_{\max }[\mathrm{Gln}]\left\{K_{\mathrm{m}}+[\mathrm{Gln}]\right\}^{-1}$ and indicates the calculated activity due only to a system with these kinetic parameters. Each value represents the mean \pm SEM of 6-14 inner call masses per experiment, from three experiments for both $\mathrm{Na}^{+}$-dependent and $\mathrm{Na}^{+}$-independent uptake.

transported by system A, its inhibition of glutamine uptake by inner cell masses suggests the presence of system $A$ activity in these cells. Thus this system, previously shown to be absent from preimplantation mouse embryos (Van Winkle et al., 1985), has now been located in inner cell masses. Furthermore, uptake of both glycine and leucine was inhibited to the same extent by MeAIB as was glutamine uptake. Both of these amino acids have been shown to react with system $\mathrm{A}$ (Oxender and Christensen, 1963; Bracy et al., 1986). A further observation was that development in vitro did not appear to affect the expression or activity of this system A in inner cell masses, within the precision of these studies. As in vitro culture has been observed to affect amino acid transport systems (Van Winkle, 1988), this observation suggests that the inner cell mass cells are protected from these environmental effects. However, the variances in these data require further investigation before this observation can be confirmed.

Kaye et al. (1982) showed a very low uptake of $\left[{ }^{14} \mathrm{C}\right] \mathrm{MeAIB}$ by blastocysts during incubation for $2 \mathrm{~h}$. But later inhibition studies with MeAIB failed to indicate the presence of system A in whole blastocysts (Van Winkle et al., 1985). The present results suggest the long incubation period used by Kaye et al. (1982) may have allowed uptake by inner cell masses to contribute to total uptake in blastocysts; this may have been insignificant over the 5-10 min uptake typical of kinetic studies. Thus the location of system A in the inner cell mass may have made it difficult for earlier investigators to reveal its presence in whole blastocysts. 


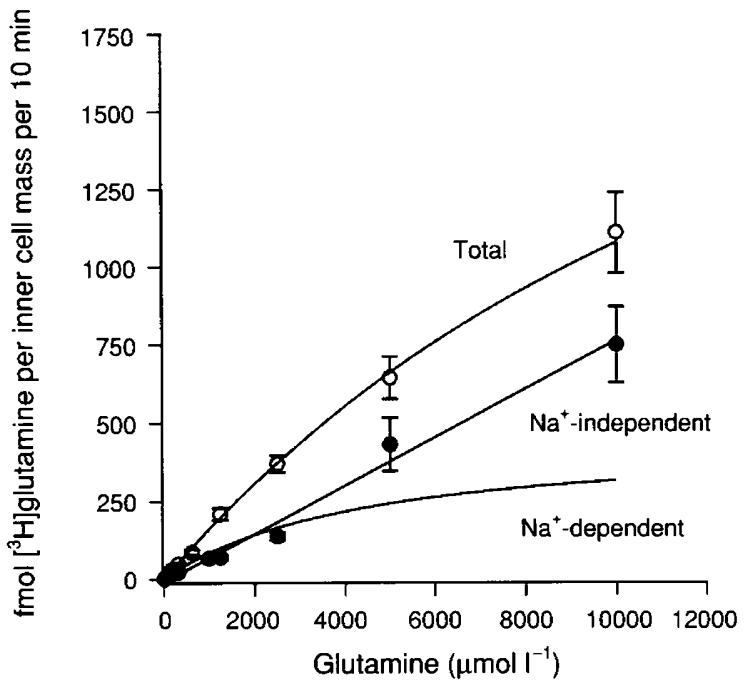

Fig. 7. Kinetics of glutamine uptake by mouse inner cell mass cells at $37^{\circ} \mathrm{C}$ in the presence of $20 \mathrm{mmol}$ Lys $\mathrm{l}^{-1} \pm \mathrm{Na}^{+}$. Inner cell masses were collected from expanded blastocysts ( $96 \mathrm{~h}$ after hCG treatment) developed in vivo or during culture for $48-52 \mathrm{~h}$, from the two-cell stage in BMOC2, or from blastocysts. The curve for total uptake $(\supset)$ is fitted to the equation $v=\mathrm{K}_{\mathrm{o}}[\mathrm{Gln}]+\left(\left\{V_{\max }[\mathrm{Gln}]\right\}\left\{\mathrm{K}_{\mathrm{m}}+[\mathrm{G} \ln ]\right\}^{-1}\right)$, with $K_{o}$ set to $77 \mathrm{pl}$ per inner cell mass per 10 min obtained from $\mathrm{Na}^{+}$-independent uptake data by linear regression $(\bullet)$. The curve for $\mathrm{Na}^{+}$-dependent uptake was fitted to the equation $v=V_{\max }[\mathrm{Gln}]\left\{K_{\mathrm{m}}+[\mathrm{Gln}]\right\}^{-1}$, and indicates the calculated activity due only to a system with these kinetic parameters. Each point represents the mean \pm SEM from two experiments, each using in vitro or in vivo developed blastocysts containing 5-10 embryos per treatment per experiment.

At $13 \mu \mathrm{mol} \mathrm{I}^{-1}$ glutamine uptake in cell masses was about $75 \% \mathrm{Na}^{+}$-dependent. The inhibition of $\mathrm{Na}^{+}$-independent glutamine uptake by Lys may indicate a contribution by system $\mathrm{b}^{\mathrm{O}+}{ }^{+}$, which is $\mathrm{Na}^{+}$-independent and transports both zwitterionic and cationic amino acids such as Lys. Further studies of this system in inner cell masses are underway. A contribution by system $\mathrm{L}$ is also suggested from the $\mathrm{BCH}$ inhibition of $\mathrm{Na}^{+}$-independent glutamine uptake (M. B. Jamshidi and P. L. Kaye, unpublished data).

In the methionine studies, the presence of systems $\mathrm{L}$ and $\mathrm{A}$ in inner cell masses was implied from inhibition profiles, providing some support for the presence of these systems in inner cell masses (Miller and Schultz, 1985). However this study was performed before characterization of systems $\mathrm{B}^{\mathrm{o},+}$ and $b^{0,+}$ (Van Winkle ef al., 1985).

In conclusion, the results indicate that inner cell masses take up glutamine by a combination of the activity of several systems. The predominant $\mathrm{Na}^{+}$-dependent system is $\mathrm{B}^{\mathrm{0},+}$, which is first expressed in eight-cell mouse embryos and is present in whole blastocysts. These observations therefore suggest that $\mathrm{B}^{\mathrm{O}+}$ is expressed in both cell lines of the blastocyst established at compaction and that expression continues throughout the establishment of the inner cell mass. A second important $\mathrm{Na}^{+}$-dependent system is expressed in inner cell masses, and has not been reported previously in blastocysts or embryos at earlier stages. This system has the identifying characteristic of sensitivity to inhibition by MeAIB and is thus concluded to be system A. Similar inhibition of uptake of glycine and leucine by MeAIB suggests that system A also contributes to the uptake of these amino acids in inner cell masses. $\mathrm{Na}^{+}$-independent uptake contributes only about $20 \%$ to the total uptake of $13 \mu \mathrm{mol}$ glutamine $\mathrm{I}^{-1}$, and inhibition by Lys, Trp and $\mathrm{BCH}$ suggests contributions by systems $\mathbf{b}^{\mathrm{O}+}$ and $\mathrm{L}$.

The cells of the blastocyst thus express the amino acid transport activities necessary to gain access to significant supplies of uterine amino acids. The tight junctions and relative impermeability of the trophectoderm to amino acids would otherwise limit this access to the abundant sources in the uterine fluids. Since in other cells, system A is subject to substrate and other regulatory factors (Kilberg, 1986), its expression in inner cell masses implies the need for more complex regulation of this supply to the inner cell mass. The recent isolation of the DNA sequence for this transporter system (Kong et al., 1993) provides a tool to demonstrate molecular differentiation of the inner cell mass from the trophectoderm.

This work was supported by a project grant from the National Health and Medical Research Council of Austalia to P. L. Kaye.

\section{References}

Brinster RL (1965) Studies on the development of mouse embryos in vitro. IV. Interaction of energy sources Journal of Reproduction and Fertility 10 $227-240$

Bracy DS, Handlogten ME, Barber EF, Han H-P and Kilberg MS (1986) Cisinhibition, trans-inhibition, and repression of hepatic amino acid transport mediated by system A Journal of Biological Chemistry 261 1514-1520

Chatot CL, Tasca RJ and Ziomek CA (1990) Glutamine uptake and utilisation by preimplantation mouse embryos in $\mathrm{CZB}$ medium Journal of Reproduction and Fertility $89335-346$

Eagle H (1955) Nutrition needs of mammalian cells in tissue culture Nature 122 501-504

Fulton BP and Whittingham DG (1978) Activation of mammalian oocytes by intracellular injection of calcium Nature 273 149-151

Gardner DK and Leese HJ (1990) Concentration of nutrients in mouse oviduct fluid and their effects on embryo development and metabolism in vitro Journal of Reproduction and Ferility 88 361-368

Gardner DK, Clarke RN, Lechene CP and Biggers JD (1989) Development of a noninvasive ultramicrofluorometric method for measuring net uptake of glutamine by single preimplantation mouse embryos Gamete Research 24 $427-438$

Harvey MB and Kaye PL (1990) Insulin increases the cell number of the inner cell mass and stimulated morphological development of mouse blastocysts in vitro Development $110963-967$

Hobbs JG and Kaye PL (1985) Glycine transport in mouse eggs and preimplantation embryos Journal of Reproduction and Fertility 74 77-86

Hobbs JG and Kaye PL (1986) Glycine and $\mathrm{Na}^{+}$transport in preimplantation mouse embryos Joumal of Reproduction and Fertility 77 61-66

Hobbs JG and Kaye PL (1990) Glycine uptake in preimplantation mouse embryos: kinetics and effects of external $\left[\mathrm{Na}^{+}\right]$Reproduction, Fertility and Development 2 651-660

Hogan B, Constantini F and Lacey E (1986) Manipulating the Mouse Embryo: a Laboratory Manual. Cold Spring Harbor Press, New York

Kaye PL, Schultz GA, Johnson MH, Pratt PM and Church RB (1982) Amino acid transport and exchange in preimplantation mouse embryos Journal of Reproduction and Fertility 65 367-380

Kilberg MS (1986) System A-mediated amino acid transport: metabolic control at the plasma membrane Trends in Biochemical Sciences 11 183-186

Kong CT, Yet SF and Lever JE (1993) Cloning and expression of a mammalian $\mathrm{Na}^{+}$/amino acid cotransporter with sequence similarity to $\mathrm{Na}^{+} /$glucose cotransporters Journal of Biological Chemistry 268 1509-1512 
Lewis A McD and Kaye PL (1992) Characterisation of glutarnine uptake in mouse two-cell embryos and blastocysts Journal of Reproduction and Ferfility $95221-229$

Miller JGO and Schultz GA (1985) Amino acid transport in mouse blastocyst components Journal of Embryology and Experimental Morphology 89 149-158

Miller JGO and Schultz GA (1987) Amino acid content of preimplantation rabbit embryos and fluid of the reproductive tract Biology of Reproduction 36 $125-129$

Oxender DL and Christensen HN (1963) Distinct mediating systems for the transport of neutral amino acids by the Ehrlich cell Journal of Biological Chemistry 238 3686-3699

Pemble LB and Kaye PL (1986) Whole protein uptake and metabolism by mouse blastocysts Journal of Reproduction and Fertility 78 149-157
Rieger D and Guay P (1988) Measurements of the metabolism of energy substrates in individual bovine blastocysts Joumal of Reproduction and Fertility 83 585-591

Solter D and Knowles B (1975) Immunosurgery of the blastocysts Proceedings of the National Academy of Sciences USA 72 5099-5102

Van Winkle LJ (1988) Amino acid transport in developing animal oocytes and early conceptuses Biochimica et Biophysica Acta 947 173-208

Van Winkle LJ, Christensen HN and Campione AL (1985) $\mathrm{Na}^{+}$-dependent transport of basic, zwitterionic, and bicyclic amino acids by a broadscope system in mouse blastocysts Journal of Biological Chemistry 260 $12118-12123$ 